\title{
DISKRIMINASI DALAM HUKUM PERKAWINAN (PENELITIAN ATAS HUKUM PERKAWINAN ADAT SUKU NIAS) ${ }^{1}$
}

\author{
Niken Savitri, Maria Zalukhu \\ Fakultas Hukum Universitas Katolik Parahyangan \\ Jl. Ciumbuleuit 94 Bandung 40141 \\ Email: niken@unpar.ac.id
}

\begin{abstract}
State obligations under CEDAW, among others, is to eliminate discrimination against women in marriage according article 16 and ensure the rights of rural women according article 14. The obligation of the State is undertaking appropriate measures to minimize discrimination and ensure the protection of women's rights in accordance CEDAW. This study tried to find some discriminations against women in Nias in terms of marriage customary law and what State's obligations on eliminating the issues. The research showed that the requirements and implementation of Nias marriage customary law has violated Marriage Act in Indonesia and results on discrimination against women's rights in marriage.
\end{abstract}

Keywords: Nias Customary Law; Marital Law; Discrimination; CEDAW.

\begin{abstract}
Abstrak
Kewajiban negara di bawah CEDAW, antara lain, adalah untuk menghilangkan diskriminasi terhadap perempuan dalam perkawinan menurut Pasal 16 dan menjamin hak-hak perempuan pedesaan menurut pasal 14. Penelitian ini mencoba untuk menemukan diskriminasi terhadap perempuan dalam hukum adat perkawinan Nias dan kewajiban Negara berdasarkan Konvensi CEDAW. Hasil penelitian menunjukkan bahwa persyaratan dan pelaksanaan Nias perkawinan hukum adat telah melanggar UU Perkawinan di Indonesia dan berdampak pada adanya diskriminasi terhadap hak-hakperempuan dalam perkawinan.
\end{abstract}

Kata kunci: Hukum Adat Nias; Hukum Perkawinan; Diskriminasi; CEDAW.

\section{A. Pendahuluan}

1. Latar Belakang Permasalahan

Bangsa Indonesia adalah bangsa yang terdiri dari berbagai jenis suku, bahasa dan kebudayaan. Tercatat sekurangnya ada 1.340 suku bangsa di Indonesia. Sistem perkawinan adat merupakan salah satu tradisi dari suatu suku bangsa yang masih berlaku dalam masyarakat adat Indonesia dalam melangsungkan perkawinan. Salah satu suku bangsa di wilayah Negara Kesatuan Republik Indonesia yang masih mempertahankan tradisi perkawinan adat adalah suku Nias. Masyarakat Adat Nias merupakan kelompok masyarakat yang terbentuk dari kesatuan masyarakat komunal yang kuat (kampung, marga, keluarga besar). Untuk mengatur kehidupan bersama dalam suatu ikatan, masyarakat adat Nias, diatur oleh suatu aturan adat (goigoi hada), yang harus ditaati oleh setiap warganya.

Nias terletak \pm 85 mil laut dari Sibolga (daerah Provinsi Sumatera Utara). Nias adalah gugusan pulau yang jumlahnya mencapai 132 pulau, membujur di lepas pantai barat Sumatera menghadap Samudra Hindia. Ada lima pulau besar yang dihuni oleh manusia, yaitu Pulau Nias $\left(9.550 \mathrm{~km}^{2}\right)$, Pulau Tanah Bala $\left(39,67 \mathrm{~km}^{2}\right)$, Pulau Tanah Masa $\left(32,16 \mathrm{~km}^{2}\right)$, Pulau Tello $\left(18 \mathrm{~km}^{2}\right)$, dan Pulau Pini $\left(24,36 \mathrm{~km}^{2}\right)$. Luas wilayah kepulauan Nias adalah 3.495,40 km2 (4,88 \% dari luas wilayah Provinsi Sumatera Utara), berada di sebelah barat Pulau Sumatera serta dikeliling oleh Samudera Hindia. ${ }^{2}$

\footnotetext{
1.Artikel ini merupakan hasil penelitian.

2.Badan Pusat Statistik kabupaten Nias, 2012, "Nias Dalam Angka", Badan Penelitian, Pengembangan dan Statistik Kabupaten Nias, hlm xxi-xxii.
} 
Kaidah hukum yang mengatur perkawinan di Indonesia telah dirumuskan dalam Undang-undang Nomor 1 tahun 1974. Dengan diberlakukannya peraturan perkawinan tersebut secara unifikasi, maka seluruh perkawinan yang dilaksanakan di wilayah Indonesia harus tunduk dan taat pada pengaturan yang ada dalam peraturan tersebut. Tak terkecuali seluruh perkawinan yang dilaksanakan secara adat oleh setiap suku bangsa yang ada di Indonesia, termasuk oleh masyarakat Nias di Gunungsitoli. Namun tata cara perkawinan adat Nias telah tidak menjadikan Undang-undang Perkawinan tersebut sebagai dasar pengaturan dalam perkawinan yang utama. Kenyataan yang terjadi adalah masyarakat adat Nias justru lebih mengutamakan tata cara perkawinan dengan menggunakan hukum adat Nias.

Dalam Perkawinan adat Nias, laki-laki dan perempuan memiliki perbedaan kedudukan, sejak pra-perkawinan hingga di dalam perkawinan bahkan hingga, apabila kemudian perkawinan tersebut berakhir. Perbedaan kedudukan ini dipengaruhi oleh kedudukan perempuan dalam status sosialnya di dalam pola kehidupan masyarakat adat Nias. Dalam masyarakat Nias, perempuan memiliki status yang lebih rendah dibandingkan laki-laki, karena laki-laki dianggap sebagai pemimpin dan lebih kuat. Oleh karena itu di segala lini kehidupan sosial dan budaya, perempuan tidak banyak ikut berperan. Dari struktur budaya kedudukan pria dan wanita sangat berbeda. Dalam pandangan masyarakat adat Nias, wanita adalah kaum lemah dan harus menurut pada pria, bahkan masyarakat masih menganggap bahwa wanita adalah pembelian dimana hal ini terlihat pula dalam tata cara perkawinan adat Nias. Perempuan Nias memiliki hak yang lebih kecil dibanding laki-laki, dengan kewajiban yang lebih banyak dibandingkan laki-laki. Misalnya perempuan lebih banyak memiliki kewajiban di dapur dan di kebun dan tidak memiliki hak yang sama untuk menempuh pendidikan. Hak dan kewajiban yang tidak sama ini juga kemudian berpengaruh pada harta kekayaan dalam keluarga selama perkawinan.
Tata-tertib perkawinan adat Nias yang berbentuk tidak tertulis serta asas-asas perkawinan adat yang mereka anut banyak ditentukan oleh para pengetua adat. Sebelum dilaksanakannya perkawinan, kesepakatankesepakatan dibuat oleh kedua belah pihak namun diputuskan oleh pengetua adat. Demikian pula hak dan kewajiban suami istri yang tidak setara, misalnya kedudukan lakilaki dan perempuan dalam perkawinanya keseluruhannya ditentukan dan diatur oleh pengetua adat. Ketidaksetaraan kedudukan antara perempuan dan laki-laki sebelum dan selama perkawinan, menyebabkan perempuan tidak dapat menikmati akses yang sama dengan laki-laki terhadap kesejahteraan dan penikmataan atas Hak Asasi Manusianya. Padahal perempuan seperti halnya laki-laki, sebelum, selama dan sesudah perkawinan, layak mendapatkan pemenuhan atas hak asasinya sebagai haknya yang kodrati sebagai manusia.

Pemerintah Indonesia telah meratifikasi Convention on the Elimination of all forms of Discrimination Against Women (Konvensi CEDAW) pada tahun 1984 dengan mengundangkannya melalui UndangUndang Nomor 7 Tahun 1984 tentang Pengesahan Konvensi mengenai Segala Bentuk Diskriminasi terhadap Wanita. Artinya Konvensi CEDAW berlaku sebagai sebuah peraturan yang mengikat bagi pemerintah Indonesia dengan disertai kewajiban yang melekat untuk melaksanakannya. Kewajiban pemerintah yang berkaitan dengan pernikahan adat dan ketidak-setaraan status dan posisi isteri dan suami dalam perkawinan di dalam Konvensi CEDAW adalah Pasal 3 serta Pasal 14 ayat (1) dan ayat (2).

Dengan pemberlakuan hukum adat perkawinan Nias yang mengadopsi nilai-nilai masyarakat yang berdampak pada adanya pembedaan perlakuan dan penikmatan atas Hak Asasinya sebagai perempuan sebelum, selama dan sesudah perkawinan, berarti pemerintah Indonesia belum dapat memenuhi kewajibannya seperti yang telah disepakatinya dalam Konvensi CEDAW. Hal ini memunculkan permasalahan yang menjadi obyek penelitian dalam tulisan ini, 
yaitu adanya indikasi diskriminasi dan tidak terpenuhinya jaminan hak asasi manusia perempuan pada masyarakat Nias dengan diterapkannya hukum adat perkawinan Nias, sekaligus diabaikannya Undang-Undang Perkawinan Nomor 1 Tahun 1974.

\section{Metode Penelitian}

Penelitian ini menggunakan metode yuridis normatif, yang melihat bagaimana kaidah hukum berupa Undang-Undang Perkawinan Nomor 1 Tahun 1974 dan Undang-undang Nomor 7 tahun 1984 diimplementasikan. Selain dari sumbersumber hukum berupa perundangan, referensi teori didapatkan dari buku-buku dan juga wawancara informal dengan petugas Catatan Sipil di kota Gunungsitoli serta beberapa pemuka adat masyarakat Nias. Pada penelitian ini tidak akan dikaji lebih lanjut tentang hukum perkawinan di Indonesia dalam kaitannya dengan pemberlakukan hukum adat perkawinan Nias. Pengkajian permasalahan dalam penelitian ini hanya dibatasi pada dampak perkawinan menurut adat Nias pada diskriminasi terhadap perempuan.

\section{Kerangka Teori}

Perempuan, sebagai suatu kelompok dalam masyarakat di dalam suatu Negara, merupakan kelompok yang juga wajib mendapatkan jaminan atas hak-hak yang dimilikinya secara asasi. Deklarasi Universal Hak Asasi Manusia (DUHAM 1948) memang tidak menyatakan secara eksplisit tentang adanya jaminan hak asasi terhadap kelompok perempuan secara khusus, namun dalam Pasal 2 DUHAM dimuat bahwa hak dan kebebasan perlu dimiliki oleh setiap orang tanpa diskriminasi, termasuk tidak melakukan diskriminasi berdasarkan jenis kelamin. ${ }^{3}$

Di Indonesia, jaminan atas hak asasi manusia secara umum bisa ditemui di dalam Undang-Undang Dasar 1945 amandemen kedua Pasal 28 A-J dan Undang-Undang Nomor 39 Tahun 1999 tentang HAM. Lebih khusus lagi, jaminan atas hak asasi perempuan dapat ditemui dalam UndangUndang Nomor 7 Tahun 1984 tentang
Penghapusan Diskriminasi terhadap Perempuan atau Pengesahan Konvensi Perempuan. Di dalam Undang-Undang No. 7 Tahun 1984 tersebut dinyatakan bahwa Negara akan melakukan upaya semaksimal mungkin untuk menghapuskan segala bentuk diskriminasi terhadap perempuan, termasuk adanya kekerasan terhadap perempuan, baik yang meliputi kekerasan di wilayah publik maupun di wilayah domestik. Dalam artikel 2 point c Konvensi CEDAW disebutkan bahwa Negara-negara peserta mengutuk diskriminasi terhadap perempuan dalam segala bentuknya, menyetujui untuk menjalankan dengan segala cara yang diperlukan dan tanpa penundaan suatu kebijakan untuk penghapusan diskriminasi terhadap perempuan dan, untuk hal ini, melakukan :

- Menetapkan perlindungan hukum bagi hak-hak perempuan atas dasar yang sama dengan laki-laki dan menjamin melalui pengadilan nasional yang berkompeten dan lembaga publik lainnya perlindungan efektif bagi perempuan dari segala tindak diskriminasi.

Dalam Konvensi CEDAW tersebut, diskriminasi terhadap perempuan diberikan pengertian sebagai "segala pembedaan, pengucilan atau pembatasan yang dibuat atas dasar jenis kelamin yang mempunyai dampak atau tujuan untuk mengurangi atau meniadakan pengakuan, penikmatan atau penggunaan hak asasi manusia dan kebebasan-kebebasan pokok di bidang politik, ekonomi, sosial, budaya, sipil atau bidang lainnya oleh perempuan, terlepas dari status perkawinan mereka, atas dasar kesetaraan antara laki-laki dan perempuan".

\section{B. Hasil dan Pembahasan}

\section{Hukum Adat Perkawinan Nias Dan Hukum Perkawinan Indonesia}

Masyarakat hukum adat Nias hidup menurut aturan adat (goigoi hada) dan kebiasaan adat seperti telah ditetapkan oleh nenek moyang dalam suatu kesepakatan adat (fondrakö). Pelaksanaan perkawinan termasuk dalam hukum adat yang diatur di

\footnotetext{
3.Saparinah Sadli, Hak Asasi Perempuan adalah Hak Asasi Manusia, dalam Pemahaman Bentuk-bentuk Tindak Kekerasan terhadap Perempuan dan Alternatif Pemecahannya, KK Convention Watch, Pusat Kajian Wanita dan Jender, Jakarta, Universitas Indonesia, 2000, hlm. 1.
} 
dalam fondrakõ, dimana hukum adat ini terbentuk atas kesepakatan atau musyawarah adat (fondrakö zi ha'uga mo'ina), yang dihadiri oleh pengetua-pengetua adat yang disebut Si'ulu, Balugu, dan Tuhenöri. Fondrakõ adalah pedoman atau pegangan dasar masyarakat Nias yang terdiri dari berbagai norma, hukum dan aturan atau juga dapat dilihat sebagai norma etis-yuridis dalam hidup bermasyarakat. ${ }^{4}$ Hukum adat yang telah disepakati bersama oleh pengetuapengetua adat bersama dengan masyarakat bersifat mengikat dimanapun mereka berada serta mewajibkan masyarakatnya tunduk terhadap aturan adat tersebut. Demikian juga dengan hukum adat yang mengatur tentang perkawinan mengikat masyarakat adat Nias yang melangsungkan perkawinan, bahkan bila perkawinan dilakukan di luar wilayah Nias.

Suku Nias adalah suku mayoritas yang tinggal di Kepulauan Nias, selain suku Batak, Minang dan Jawa. Dalam bahasa aslinya, orang Nias menamakan diri mereka "Ono Niha" $($ Ono $=$ anak/keturunan; Niha $=$ manusia atau Anak Manusia) dan pulau Nias disebut "Tanö Niha" (Tanö = tanah, Niha = manusia atau Tanah Manusia) sedangkan orang lain disebut Ndrawa (pendatang dari luar,atau orang luar). ${ }^{5}$ Masyarakat Adat Nias menganut sistem komunal. Sistem komunal tersebut terlihat juga dalam proses perkawinan adat Nias, dimana berlangsungnya suatu perkawinan selalu melibatkan keluarga kedua mempelai dan masyarakat adat.

Sistem perkawinan adat Nias adalah sistem perkawinan (fangowalu) dengan menarik garis keturunan secara patrilineal (nga'õtõ moroi khõ ama). Masyarakat patrilineal (kebapaan) yaitu masyarakat yang menarik garis keturunan dari pihak laki-laki (ayah) saja. ${ }^{6}$ Dalam sistem perkawinan, masyarakat $\mathrm{Nias}$ masih sangat mengutamakan sistem perkawinan adat dengan semua tata cara dan pengaturannya baik sebelum maupun di dalam perkawinan. Demikian juga posisi dan status isteri dan suami dalam perkawinan, meskipun mendapatkan pengaruh dari agama yang dianut oleh masyarakatnya, namun juga dipengaruhi sangat kuat oleh adat dan tradisi masyarakat Nias. Sedangkan pengaturan perkawinan menurut hukum nasional menjadi kaidah yang mengatur namun bersifat suplementer (tambahan) setelah dipenuhinya kaidah hukum adat.

Kaidah yang mengatur perkawinan dalam masyarakat adat Nias adalah kaidah adat yang dilestarikan secara turun-temurun oleh nenek moyang suku Nias dan masih dipertahankan hingga saat ini. Setiap tahapan perkawinan memiliki makna dan nilai yang sangat dijunjung tinggi. Akan tetapi, seiring dengan perkembangan zaman banyak pihak menilai bahwa proses dalam perkawinan adat Nias membutuhkan waktu dan biaya yang sangat besar sehingga memberatkan pihak yang melaksanakan pesta. Seperti pemberian jujuran yang harus diberikan oleh pihak mempelai laki-laki kepada keluarga mempelai perempuan yang merupakan Bowõ bõli niha, dan terdiri dari " 5 gana'a, 4 mbawi, 2 mbalaki, 2 ziwalu, sambua zese”. Dari uraian beberapa pemuka Adat dalam sebuah perkawinan, pemberian mas kawin untuk terjadinya perkawinan adalah 5 emas, 4 babi, 2 perak, 2 perunggu, dan 1 zese (ukuran uang terkecil untuk adat Nias). Fungsi jujur yaitu dengan dibayarnya jujur maka masuklah istri menjadi bagian dari kelompok suaminya.?

Akibat dari persyaratan jujuran yang begitu banyak telah memberikan dampak yang sangat besar terhadap kesejahteraan masyarakat Nias. Setiap keluarga yang akan melangsungkan pernikahan harus bekerja

\footnotetext{
4. Albinus Fombagi Fau, "Fondrakõ_Suatu Uraian Etis-kritis atas Nialai-nilai Fondrakõ dalam kehidupan Masyarakat Nias", Skripsi, Pematangsiantar, 1997, hlm 1.

5. Pastor Johannes Maria Hämmerle, OFMCap, 2001, Asal-Usul Masayarakat Nias, Gunungsitoli, Penerbit Yayasan Pusaka Nias, hlm 119.

6. Djaren Saragih, 1980, Hukum Perkawinan Adat dan Undang-Undang Tentang Perkawinan Serta Peraturan Pelaksananya, Bandung, Tarsito, hlm 8.

7. Christina Yulniasta Zalukhu, Yansalzi Sastry, Yofiza Media, "Perkawinan Jujur Bagi Masyarakat Adat Nias di Kecamatan Lahewa Kabupaten Nias Utara”, Jurnal Hukum Faculty of Law Bung Hatta University, Vol. 3, No. 1, 2013, hlm. 3 .
} 
keras agar semua biaya perkawinan yang telah dikeluarkan dapat terlunasi, karena masyarakat Nias dalam membiayai pesta dibantu oleh semua keluarga dan itu merupakan utang orang yang menikah dan harus di bayar di kemudian hari. Keadaan semakin buruk karena sebagian besar masyarakat Nias masih berpendidikan rendah sehingga perkembangan daerah Nias di nilai tertinggal dibandingkan dengan daerahdaerah lain, baik dari segi pendidikan maupun dari segi Sumber Daya Manusia (SDM), meskipun sumber daya alam Nias kaya dan berlimpah.

Dalam budaya masyarakat adat Nias kedudukan laki-laki dan perempuan sangat berbeda. Perempuan dianggap kaum lemah dan harus menurut pada laki-laki, harus selalu diperintah laki-laki, mendapatkan hak yang lebih kecil dari laki-laki, bahkan dianggap sebagai obyek pembelian laki-laki. Perempuan Nias lebih banyak menghabiskan waktu di dapur dan di kebun sehingga mereka tidak dapat melakukan hal-hal yang mereka inginkan, seperti menempuh pendidikan lebih tinggi atau bekerja di ruang publik. Dalam pelatihan-pelatihan yang diselenggarakan, prioritas ada pada laki-laki, sehingga perempuan Nias kurang dapat mengikuti perkembangan dan kemajuan tekonologi yang ada. Seiring dengan perkembangan pengetahuan dan kemajuan zaman, pendapat yang memposisikan perempuan secara berbeda ini masih belum berubah.

Dalam masyarakat adat Nias suatu perkawinan dapat berlangsung atas kehendak orang tua kedua belah pihak. Perempuan tidak dapat menentukan kehendaknya, keputusan untuk menerima atau menolak lamaran terletak di tangan pihak orang tua atau paman dari pihak perempuan (fambambatõ). Perkawinan seorang pria dan wanita pada masyarakat Nias, cenderung memiliki unsur pemaksaan, karena mereka tidak dapat menentukan pilihan mereka sendiri. Seorang wanita Nias ketika ia dewasa menurut pandangan Nias (obu'u fosu/mulai berbuah dada) sudah dianggap siap untuk menikah. Bila dilihat dari pemaknaan bõwõ, para pihak yang terlibat dalam penentuan perkawinan tersebut dapat mengambil keuntungan dari perkawinan tersebut dengan membebankan jujuran (mas kawin) pernikahan kepada kedua calon mempelai. Bõwõ yang seharusnya digunakan sebagai biaya pelaksanaan pesta cenderung menjadikan perempuan sebagai sebuah obyek jual beli, yaitu orang tua pihak perempuan menawar bõwõ yang tinggi sebagai tebusan pemberian anak perempuannya kepada pihak laki-laki.

Dalam perkawinan adat Nias, tidak dikenal adanya pencegahan perkawinan. Ini disebabkan karena tidak ada lembaga perkawinan adat yang secara khusus menangani perkawinan. Ketika sebuah perkawinan dilaksanakan, yang terlibat adalah para tokoh-tokoh adat. Namun, dalam perkembangan dengan masuknya pengaruh agama dalam masyarakat Nias, maka pencegahan dan pembatalan perkawinan dapat dilakukan melalui Hukum Gereja. Apabila perkawinan tidak memenuhi persyaratan-persyaratan yang sesuai dengan Hukum Gereja, maka perkawinan tersebut masih belum dapat dinyatakan resmi.

Menurut hukum perkawinan, pembatalan perkawinan dapat terjadi setelah adanya keputusan dari pengadilan. Tetapi, yang terjadi di daerah kabupaten Nias selama ini tidak banyak yang mengajukan gugatan untuk dilakukannya pembatalan perkawinan ataupun perceraian. Hal ini ditunjukkan dengan data yang diperoleh dari Kantor Bidang Catatan Sipil tentang Realisasi penerbitan Akta Catatan Sipil Tahun 2012. Data ini menunjukkan penerbitan akta perceraian nol atau tidak pernah ada pasangan yang mengajukan perceraian secara resmi ke Kantor Catatan Sipil meskipun telah banyak terjadi pelanggaran terhadap perkawinan yang diatur dalam Undang-Undang Nomor 1 Tahun 1974 Tentang Perkawinan seperti diuraikan oleh petugas Kantor Catatan Sipil.

Dalam masyarakat Nias, jika terjadi perceraian dalam sebuah perkawinan maka baik harta benda maupun anak akan jatuh sepenuhnya kepada suami dan keluarganya. Istri tidak memiliki hak baik harta beda yang didapat selama perkawinan meskipun harta yang dibawa sebelum perkawinan. Kemudian pihak perempuan akan dikembalikan kepada kedua orang tuanya seperti semula. Ketika terjadi perceraian pun, anak-anak dari hasil 
perkawinan akan berada di bawah kekuasaan suami dan keluarga dari suami. Apabila, perkawinan terputus karena salah satu di antara suami atau isteri meninggal maka harta warisan akan jatuh ke tangan anak lakilaki saja, anak perempuan tidak berhak mendapatkan harta warisan, karena dianggap bahwa perempuan ketika menikah akan membawa harta tersebut kepada suami dan hal tersebut tidaklah diperbolehkan dalam adat. Meskipun perceraian dalam masyarakat adat Nias sangat jarang terjadi, akan tetapi di beberapa kasus perceraian dalam masyarakat Nias, perceraian hanya boleh diajukan oleh pihak suami saja.

\section{Diskriminasi Dalam Hukum Adat Perkawinan Nias}

Bila mengacu pada pengertian diskriminasi yang telah diuraikan dalam bagian tulisan ini sebelumnya, maka pemberlakuan hukum adat Nias dalam bidang perkawinan tersebut telah menempatkan perempuan pada posisi di mana terjadi pembatasan yang berdampak pada pengurangan atas pengakuan dan penikmatan hak-hak dasar perempuan, baik dalam membuat keputusan untuk menikah dan memilih suami, kekuasaan orang tua terhadap anak, hingga penguasaan terhadap harta benda dalam perkawinan dan pemutusan perkawinan. Padahal menurut Undangundang Perkawinan suami dan istri memiliki hak dan kedudukan yang seimbang (Pasal 31 ayat 1 dan 2 Undang-undang Nomor 1 tahun 1974 tentang Perkawinan). Hak dan kedudukan yang sama tersebut dijamin oleh konstitusi. Perempuan dalam perkawinan memiliki hak konstitusional yang sama dengan laki-laki, karena setiap perempuan adalah juga warga negara yang memiliki hak konstitusional yang sama dengan warga negara yang lain yaitu laki-laki. ${ }^{8}$

Perkawinan adalah satu tahapan kehidupan di mana seseorang mengikatkan diri dengan orang lain untuk menjalankan kewajiban dan mendapatkan hak sebagai suami atau isteri. Pelbagai akibat hukum melekat manakala seseorang mengikatkan diri dalam lembaga perkawinan. Karenanya proses untuk mengikatkan diri tersebut harus sepenuhnya menjadi kebebasan dan hak dasar dari tiap orang yang akan terikat dalam lembaga perkawinan tersebut. Pemenuhan hak oleh laki-laki dan perempuan setara dan sebanding dengan beban kewajiban yang harus dipenuhi oleh laki-laki dan perempuan (suami dan istri). ${ }^{9}$ Manakala perempuan ditempatkan dalam posisi tidak dapat memilih dan menentukan untuk memasuki perkawinan, serta adanya pembedaan posisi dan kedudukan di dalam perkawinan, maka pada saat itu pula terjadi pembatasan kesempatan perempuan untuk memiliki hak yang paling mendasar yang berkaitan dengan penentuan kehidupannya. Terlebih lagi bila kemudian di dalam perkawinan terjadi pembatasan pada akses ekonomi, hukum dan pendidikan, dimana perempuan dianggap tidak berhak atas pengelolaan ekonomi keluarga, tidak berhak melakukan perbuatanperbuatan hukum dan tidak berhak atas peningkatan kemampuan serta keterampilan yang dibutuhkannya sebagai haknya yang paling dasar untuk memberdayakan potensi dirinya. Pembatasan kesempatan yang bersifat mendasar, tanpa didasari oleh adanya standar obyektif tersebut dapat dikategorikan sebagai perbuatan yang bersifat diskriminatif terhadap perempuan.

Negara memiliki kewajiban berdasarkan Konvensi CEDAW untuk mengeliminasi diskriminasi tersebut. Kewajiban seperti yang telah disepakati oleh pemerintah negara Indonesia melalui peratifikasian Konvensi Perempuan berkonsekuensi pada diimplementasikannya kewajiban-kewajiban tersebut ke dalam peraturan perundangan dan pelaksanaan penegakannya. Berkaitan dengan pemberlakukan hukum Adat Nias tentang perkawinan seperti diuraikan di atas, Negara terikat untuk melaksanakan kewajiban seperti tertera dalam Konvensi Perempuan dalam artikel-artikel berikut :

Artikel 2:

Negara-negara Peserta mengutuk

8. Nuraida Jamil, "Hak Asasi Perempuan dalam Konstitusi dan Konvensi CEDAW”, Muwazah, Jurnal Kajian Gender, e-journal Sekolah Tinggi Agama Islam Negeri Pekalongan, Vol. 6, No. 2, Desember 2014, hlm. 170.

9. Rustam Dahar Karnadi Apollo Harahap, "Kesetaraan Laki-laki dan Perempuan dalam Hukum Perkawinan Islam", Sawwa, Jurnal Studi gender dan Anak, Pusat Studi Gender Dan Anak (PSGA), Universitas Islam Negeri (UIN) Walisongo Semarang, Vol. 8, No. 2, 2013, hlm.363,. 
diskriminasi terhadap perempuan dalam segala bentuknya, bersepakat untuk menjalankan dengan segala cara yang tepat dan tanpa ditunda-tunda melaksanakan kebijakan untuk menghapus diskriminasi terhadap perempuan dan, untuk mencapai

tujuan itu, melakukan:

- Tidak melakukan tindakan atau praktek diskriminasi terhadap perempuan dan memastikan bahwa pejabat dan lembaga publik bertindak sesuai dengan kewajiban ini;

- Melakukan segala langkah-tindak yang diperlukan untuk menghapus diskriminasi terhadap perempuan oleh siapapun, organisasi atau perusahaan apapun;

- Melakukan segala langkah-tindak yang diperlukan, termasuk pembuatan perundang-undangan, untuk mengubah atau menghapus undang-undang, peraturanperaturan, kebiasaan dan praktek yang ada yang diskriminatif terhadap perempuan;

Melalui artikel ini pemerintah Indonesia diwajibkan untuk membuat tindakan-tindakan positif dan aktif dalam mengeliminasi diskriminasi terhadap perempuan, utamanya yang dilakukan oleh pejabat publik, baik melalui peraturan perundangan untuk mengubah kebiasaan dan praktek yang berdampak pada diskriminasi terhadap perempuan. Dalam hal ini pemerintah diwajibkan untuk melakukan tindakan-tindakan yang secara langsung atau tidak langsung menghapuskan keberadaan hukum adat yang berdampak pada diskriminasi terhadap perempuan.

Artikel 5 :

Negara-negara Peserta wajib melakukan langkah-langkah-tindak yang tepat:

- Untuk mengubah pola tingkah-laku sosial dan budaya laki-laki dan perempuan, dengan maksud untuk mencapai penghapusan prasangka dan kebiasaan dan segala praktek lainnya yang didasarkan atas inferioritas atau superioritas salah satu jenis kelamin atau peran-peran stereotip laki-laki dan perempuan;

Hukum adat Nias yang melahirkan pembedaan terhadap perempuan dalam bidang perkawinan lahir dari pola tingkah laku sosial dan budaya masyarakat Nias yang bercorak partriarkis dan cenderung menempatkan posisi dan status perempuan pada kedudukan yang lemah dan tersisihkan dalam penguasaan anak dan harta benda dalam perkawinan. Hukum seperti itu dikategorikan hukum yang seksis, yaitu hukum yang tidak memihak kaum perempuan karena dipengaruhi oleh konstruksi sosial yang bias gender. ${ }^{10}$ Bila pemerintah Indonesia mengikatkan diri pada Konvensi maka pemerintah memiliki kewajiban untuk mengubah pola tingkah laku budaya yang cenderung memposisikan perempuan secara berbeda dan berdampak pada diskriminasi terhadap perempuan.

Artikel 10:

Negara-negara peserta wajib melakukan segala langkah-tindak yang diperlukan untuk menghapus diskriminasi terhadap perempuan untuk menjamin bagi mereka hak-hak yang setara dengan laki-laki dalam bidang pendidikan dan khususnya untuk menjamin, atas dasar kesetaraan laki-laki dan perempuan:

- Kondisi-kondisi yang sama dalam bimbingan karir dan keterampilan, dalam akses terhadap pelajaran-pelajaran dan dalam memperoleh ijazah di lembaga-lembaga pendidikan dan segala tingkatan di daerah pedesaan maupun perkotaan; kesetaraan ini wajib dijamin dalam pendidikan pra-sekolah, umum, teknik, profesional dan pendidikan teknik tinggi, serta dalam semua jenis pelatihan dan keterampilan;

Dalam artikel ini pemerintah diwajibkan untuk memberikan kesempatan yang sama dalam membuka akses terhadap pendidikan yang didapat oleh perempuan, baik di pedesaan maupun perkotaan. Dalam

10. Moch. Fakhri, Hukum Perkawinan di Indonesia, Muwazah, Jurnal Kajian Gender, Vol. 7 No. 2, hlm. $163,2015$. 
hal masyarakat menempatkan perempuan dalam posisi di ruang domestik yang menghalangi akses perempuan terhadap kemampuan dan pengetahuan mereka dalam pendidikan formal maupun informal, maka pemerintah memiliki kewajiban untuk melakukan tindakan-tindakan yang dibutuhkan.

\section{Artikel 14:}

Negara-negara Peserta wajib memperhatikan masalah-masalah khusus yang dihadapi oleh perempuan pedesaan dan peran penting perempuan pedesaan dalam mempertahankan kelangsungan hidup ekonomi keluarganya, termasuk pekerjaan mereka dalam sektor ekonomi yang tidak dinilai dengan uang, dan wajib melakukan segala langkah yang diperlukan untuk menjamin pelaksanaan ketentuan Konvensi ini bagi perempuan di daerah pedesaan;

Perempuan di pedesaan tidak memiliki akses yang sama dengan yang dimiliki oleh perempuan di perkotaan, terhadap informasi, pemberdayaan potensi, peningkatan kualitas hidup dan kesejahteraan. Karena itu Konvensi memberikan perhatian khusus kepada perempuan di pedesaan, dengan mewajibkan pemerintah memberikan tindakan-tindakan khusus kepada mereka. Termasuk dan terutama adalah akses perempuan di pedesaan dalam bidang ekonomi. Dalam artikel ini hal tersebut juga meliputi pekerjaan-pekerjaan yang tidak dinilai dengan uang, seperti halnya pekerjaan domestik yang biasanya dikerjakan oleh perempuan pedesaan. Karena itu, apabila hukum adat menempatkan perempuan di posisi domestik, negara harus menjamin perempuan pedesaan mendapatkan jaminan hak asasinya, meskipun secara ekonomi apa yang dilakukan oleh perempuan di ruang domestik tidak dapat dinilai dengan uang atau mendatangkan uang.

Artikel 16:

Negara-negara Peserta wajib melakukan langkah-tindak yang tepat untuk menghapus diskriminasi terhadap perempuan dalam semua urusan yang berhubungan dengan perkawinan dan hubungan keluarga dan khususnya wajib menjamin, atas dasar kesetaraan laki-laki dn perempuan;

- Hak-hak yang sama untuk masuk dalam ikatan perkawinan;

- Hak-hak yang sama untuk memilih dengan bebas pasangan hidupnya dan untuk masuk ke dalam ikatan perkawinan hanya dengan persetujuan bebas dan sepenuhnya;

- Hak-hak dan tanggung jawab yang sama sebagai orang-tua, terlepas dari status perkawinannya;

- Hak-hak dan tanggung jawab yang sama sebagai orang-tua, terlepas dari status perkawinannya, dalam persoalan yang berhubungan dengan anak-anak mereka; dalam semua hal kepentingan anak harus diutamakan;

$\begin{array}{ll}- & \ldots \\ - & \ldots \\ - & \ldots\end{array}$

- Hak-hak yang sama bagi kedua pasangan sehubungan dengan kepemilikan, pembelian, pengelolaan, administrasi, penikmatan dan pelepasan hak milik, baik secara Cuma-Cuma maupun dengan pertimbangan nilai harga.

Artikel ini mewajibkan negara melakukan tindakan penghapusan diskriminasi terhadap perempuan terkait dengan proses perkawinan, selama perkawinan berlangsung dan setelah perkawinan berakhir. Kesamaan hak dan kewajiban pada laki-laki dan perempuan harus dijamin oleh negara. Sehingga manakala suatu masyarakat tertentu melakukan pembedaan yang berdampak pada pembedaan posisi perempuan dan laki-laki dalam menentukan perkawinan, selama perkawinan dan hak-haknya untuk mengakhiri perkawinan serta sesudah perkawinan berakhir, maka negara bertanggung jawab untuk melakukan tindakan-tindakan yang tepat guna menghapus pemberlakukan praktik budaya tersebut. Dalam penelitian ini budaya masyarakat Nias menerapkan praktik yang berdampak pada diskriminasi terhadap perempuan sebelum, selama dan setelah perkawinan. Maka adalah kewajiban negara 
untuk mensosialisasikan dan menghapuskan praktik-praktik tersebut, baik melalui kebijakan sosial maupun peraturan perundang-undangan.

\section{Simpulan}

Penerapan hukum adat perkawinan Nias yang membatasi hak-hak perempuan Nias sebelum, selama dan setelah perkawinan adalah salah satu bentuk diskriminasi. Perempuan suku Nias telah terdiskriminasi dan tidak mendapatkan jaminan hak asasi manusianya sesuai dengan jaminan dalam Konstitusi dengan diterapkannya hukum adat perkawinan Nias, sekaligus diabaikannya Undang-undang Perkawinan Nomor 1 tahun 1974.

Dengan diratifikasinya Konvensi CEDAW, pemerintah Indonesia terikat untuk memenuhi semua kewajiban dalam Konvensi (kecuali pemerintah melakukan perkecualian untuk terikat pada beberapa artikel dalam Konvensi). Negara wajib melakukan langkah-langkah yang diperintahkan dalam Konvensi untuk menghapuskan diskriminasi tersebut termasuk dan tidak terbatas pada tindakan-tindakan untuk menerapkan hukum perkawinan secara nasional sesuai dengan Undang-Undang Nomor 1 Tahun 1974.

\section{Daftar Pustaka}

Dahar Karnadi Apollo Harahap Rustam, "Kesetaraan Laki-laki dan Perempuan dalam Hukum Perkawinan Islam”, Sawwa, Jurnal Studi gender dan Anak, Pusat Studi Gender Dan Anak (PSGA), Universitas Islam Negeri (UIN) Walisongo Semarang, Vol. 8, No. 2, 2013.

Fakhri Moch., "Hukum Perkawinan di Indonesia", Muwazah, Jurnal Kajian Gender, Vol. 7, No. 2, 2015.

Fombagi Fau Albinus, "Fondrakõ Suatu Uraian Etis-kritis atas Nialai-nilai Fondrakõ dalam kehidupan Masyarakat Nias", Skripsi, Pematangsiantar, 1997.

Jamil Nuraida, "Hak Asasi Perempuan dalam Konstitusi dan Konvensi CEDAW", Muwazah, Jurnal Kajian Gender, ejournal Sekolah Tinggi Agama Islam
Negeri Pekalongan, Vol. 6, No. 2, Desember 2014.

Maria Hämmerle Pastor Johannes, OFMCap, 2001, Asal-Usul Masayarakat Nias, Gunungsitoli, Penerbit Yayasan Pusaka Nias.

Sadli Saparinah, Hak Asasi Perempuan adalah Hak Asasi Manusia, dalam Pemahaman Bentuk-bentuk Tindak Kekerasan terhadap Perempuan dan Alternatif Pemecahannya, KK Convention Watch, Pusat Kajian Wanita dan Jender, Jakarta, Universitas Indonesia, 2000.

Saragih Djaren, 1980, Hukum Perkawinan Adat dan Undang-Undang Tentang Perkawinan Serta Peraturan Pelaksananya, Bandung, Tarsito.

Yulniasta Zalukhu Christina, Yansalzi Sastry, Yofiza Media, "Perkawinan Jujur Bagi Masyarakat Adat Nias di Kecamatan Lahewa Kabupaten Nias Utara", Jurnal Hukum Faculty of Law Bung Hatta University, Vol. 3, No. 1, 2013.

Badan Pusat Statistik kabupaten Nias, 2012, "Nias Dalam Angka", Badan Penelitian, Pengembangan dan Statistik Kabupaten Nias.

Convention on the Elimination of all forms of Discrimination Against Women (Konvensi CEDAW)

Undang-Undang Nomor 1 Tahun 1974 tentang Perkawinan 